\title{
Article
}

\section{Ground Frosts in Poland in the Growing Season}

\author{
Czesław Koźmiński, Jadwiga Nidzgorska-Lencewicz *, Agnieszka Mąkosza and Bożena Michalska
}

check for updates

Citation: Koźmiński, C.; Nidzgorska -Lencewicz, J.; Mąkosza, A.; Michalska, B. Ground Frosts in Poland in the Growing Season. Agriculture 2021, 11, 573. https://doi.org/10.3390/ agriculture11070573

Academic Editor: Piotr Prus

Received: 1 May 2021

Accepted: 19 June 2021

Published: 23 June 2021

Publisher's Note: MDPI stays neutral with regard to jurisdictional claims in published maps and institutional affiliations.

Copyright: (C) 2021 by the authors. Licensee MDPI, Basel, Switzerland. This article is an open access article distributed under the terms and conditions of the Creative Commons Attribution (CC BY) license (https:/ / creativecommons.org/licenses/by/ $4.0 /)$.
Department of Environmental Management, West Pomeranian University of Technology in Szczecin, ul. Papieża Pawła VI 3, 71-459 Szczecin, Poland; czeslaw.kozminski@zut.edu.pl (C.K.); agnieszka.makosza@zut.edu.pl (A.M.); bozena.michalska@zut.edu.pl (B.M.)

* Correspondence: jadwiga.nidzgorska-lencewicz@zut.edu.pl
Abstract: The ongoing climate warming affects, among others, and the variability of thermal conditions in spring and autumn are resulting in earlier dates of the beginning and end of the growing season. The present paper provides detailed characteristics of the phenomenon of ground frosts, addressing the question of whether the risk of frost-related damage in the extending growing season is still present. The assessment of temporal and spatial distribution of ground frosts $(5 \mathrm{~cm}$ above ground level-AGL) in Poland in the thermal growing season (AT $>5^{\circ} \mathrm{C}$ ) was conducted on the basis of the results of air temperature measurements at 5 and $200 \mathrm{~cm}$ a.g.l. obtained from 52 station of the Institute of Meteorology and Water Management-National Research Institute for the period 1971-2020. The thermal growing season was calculated using the method by Gumiński. The following were calculated: the dates of the occurrence of ground frosts in spring and autumn, duration of the frost-free period, the number of days with frosts of various intensity, according to years, ten-day period and days in a year together with trends of change. The conducted analysis demonstrated that the number of days with frosts in the thermal growing season in the multiannual period under analysis (1971-2020) does not show any statistically significant changes. It was found that in the thermal growing season, the average number of days with ground frosts in Poland amounts to 28 and ranges in spring from 15 to 22 , and in autumn from 8 to 12 . Most frequently, approx. $49 \%$, slight frosts are recorded, followed by moderate $(29 \%)$, severe $(15 \%)$ and very severe $(7 \%)$. A positive effect of water reservoirs on decreasing the frequency and intensity of frosts, as well as sporadic occurrence of the phenomenon in the second half of June were demonstrated. Statistically significant earlier dates of disappearance of frosts in spring, later dates of occurrence in autumn and the lengthening of the frost-free period from approximately 2 days in the north-east of Poland to approximately 8.0 days over 10 years in the Pomerania region, create increasingly more favourable conditions for the cultivation of plants with high thermal requirements in Poland.

Keywords: spring frosts; autumn frosts; frost-free period; intensity; tendency of changes; the number of days; dates

\section{Introduction}

According to the Glossary of Meteorology [1], frost can be defined as: (1) a decrease in air temperature below the freezing point of water during the growing period; (2) a decrease in air temperature below $0{ }^{\circ} \mathrm{C}$ during the prevailing occurrence of a positive average $24-\mathrm{h}$ period temperature; (3) a decrease in minimum air temperature below $0^{\circ} \mathrm{C}$ in a 24 -h period positive maximum temperature.

In the literature on the subject, frosts are distinguished and characterised, for example, due to: the origin i.e., advective, radiation, advective-radiation [2-7]; time of occurrencespring and autumn [3,6,8]; altitude above ground level-air frosts at $2 \mathrm{~m}$ a.g.1. [6,9,10] and ground frosts at $5 \mathrm{~cm}$ a.g.1. [9,11,12]; as well considering their intensity $[8,11,12]$ or frost-free period $[6,8,10,13]$.

The frosts recorded in Poland are generally of advective-radiation nature, owing to the approaching cold arctic air masses [14]. The studies by Koźmiński and Trzeciak [15] on the 
multiannual period 1951-1970 show that, in most regions of Poland, the last spring frosts were generally recorded from 26 April to 5 May. In turn, the analysis by Kalbarczyk [12] on the period 1966-2005 indicates later occurrence by, on average, 15 days. Also, as is indicated by Michalska [16], the occurrence of last spring frosts in Pomerania may extend even to the end of June. Generally, the occurrence of ground frosts is recorded on individual days; however, there may also be a series of two or more days $[9,17]$. With respect to the intensity of frosts, the most frequent are the frosts termed slight (to $-2{ }^{\circ} \mathrm{C}$ ) or moderate $\left(-2\right.$ to $\left.-4{ }^{\circ} \mathrm{C}\right)$, and severe $\left(4-6{ }^{\circ} \mathrm{C}\right)$ and very severe frosts $\left(>6^{\circ} \mathrm{C}\right)$ are recorded much less frequently $[8,9,11]$. The average ground frost-free period in Poland, according to the study by Kalbarczyk [12] on the period 1966-2010, is 120-150 days. However, in Pomerania, the period can extend to 130-160 days [16] and in north-western Poland it is by far shorter and lasts, on average, 112-145 days [9].

In Poland, agricultural and orchard cultivation is at risk of spring and late-spring ground frosts ( $5 \mathrm{~cm}$ a.g.l.), particularly during the approach of cold air masses after the period of significant warming in spring, which is conducive to premature vegetation growth (the so-called "false spring") [18]. A particular risk to plants occurs during the period of flower buds occurrence, flowering and fruit setting. Ground frosts are characterised by a marked temporal and spatial discontinuity owing to the irregular approach of arctic air masses and diverse physiographic conditions such as: altitude above sea-level, topography and land cover, the nature of the ground, hydrographic network and slope exposure etc. $[19,20]$. Consequently, the issue of frosts is of interest to farmers, gardeners, fruit growers, foresters and meteorologists who, for many years, have been analysing the occurrence and damage caused by frosts, as well as establishing preventive actions [14,16,21-27].

Polish literature on the subject of frosts is extensive. Owing to the size of the area under study, it is possible to distinguish studies presenting the phenomenon on a local scale $[3,11,21,28]$, regional scale $[8,14,29,30]$ and nationwide scale $[10,15,17,31,32]$. Additionally, the issue of frosts is a permanent constituent of monographs and handbooks on the climate and agro-climate of Poland [16,21,33-35]. The studies on the direct and consequential effects of frosts on the growth of plants and the extent of loss are of particular relevance. Poor health condition of plants and an increased vulnerability to various diseases is observed particularly during the period of unfavourable weather conditions $[12,16,21,25,36]$.

The studies referred to in the present paper discuss frosts per adopted time period referred to as the growing season covering, generally, the period from April to October. Given the consequences of the global warming to agriculture, it may be assumed that with a positive trend of air temperature [37-42], the vegetation starts earlier in spring [32,43-46] which results in temporal changes in the phenological phases of plants [47-49]. As is stated in the aforementioned research studies, the greatest warming is observed in winter, as well as in February, March, May and August. The increasing occurrence of mild winter [50] disturbs the plant dormancy period and, with the occurrence of spring frosts, poses a significant risk to plants $[16,27,36,49,51]$. The increasing air temperature particularly in late winter and early spring contributes to an earlier occurrence and, consequently, the extension of the thermal growing season. According to studies, in Poland it is, on average, by 3-4 days and as many as 8 days over the period of 10 years in the northern part of Poland $[45,52,53]$. Moreover, due to changes in air temperature, the dates of the beginning and end of the growing season change as well. Greater changes are observed regarding the dates of the beginning which show a trend of the growing season beginning earlier [32,54].

On the one hand, the ongoing global warming, an increase in thermal resources in the area of Poland and an earlier dates of the beginning of the growing season are advantageous to farmers and gardeners who can increase the acreage of thermophilic plants cultivation [55]. On the other hand, in the case of early sowing or planting in spring, there is an increased risk of frost damage [11,28,36,56,57]. The future climate change predictions also show the increased risk of frosts when they occur after the initiation of vegetation in spring [58]. 
In the light of the above, the aim of the present paper is to provide a characteristics of ground frosts $(5 \mathrm{~cm}$ a.g.l) of different intensities in Poland considered in the context of the extension of the growing season $\left(\mathrm{AT}>5^{\circ} \mathrm{C}\right.$ ) and not just on the calendar basis (April-October), which is predominant in the literature on the subject.

\section{Materials and Methods}

The present paper makes use of the results of mean 24-h period air temperature measurements taken at $200 \mathrm{~cm}$ a.g.l., and the minimum air temperature at $5 \mathrm{~cm}$ a.g.l. obtained from 52 meteorological stations of the Institute of Meteorology and Water ManagementNational Research Institute in the period 1971-2020 (Figure 1).

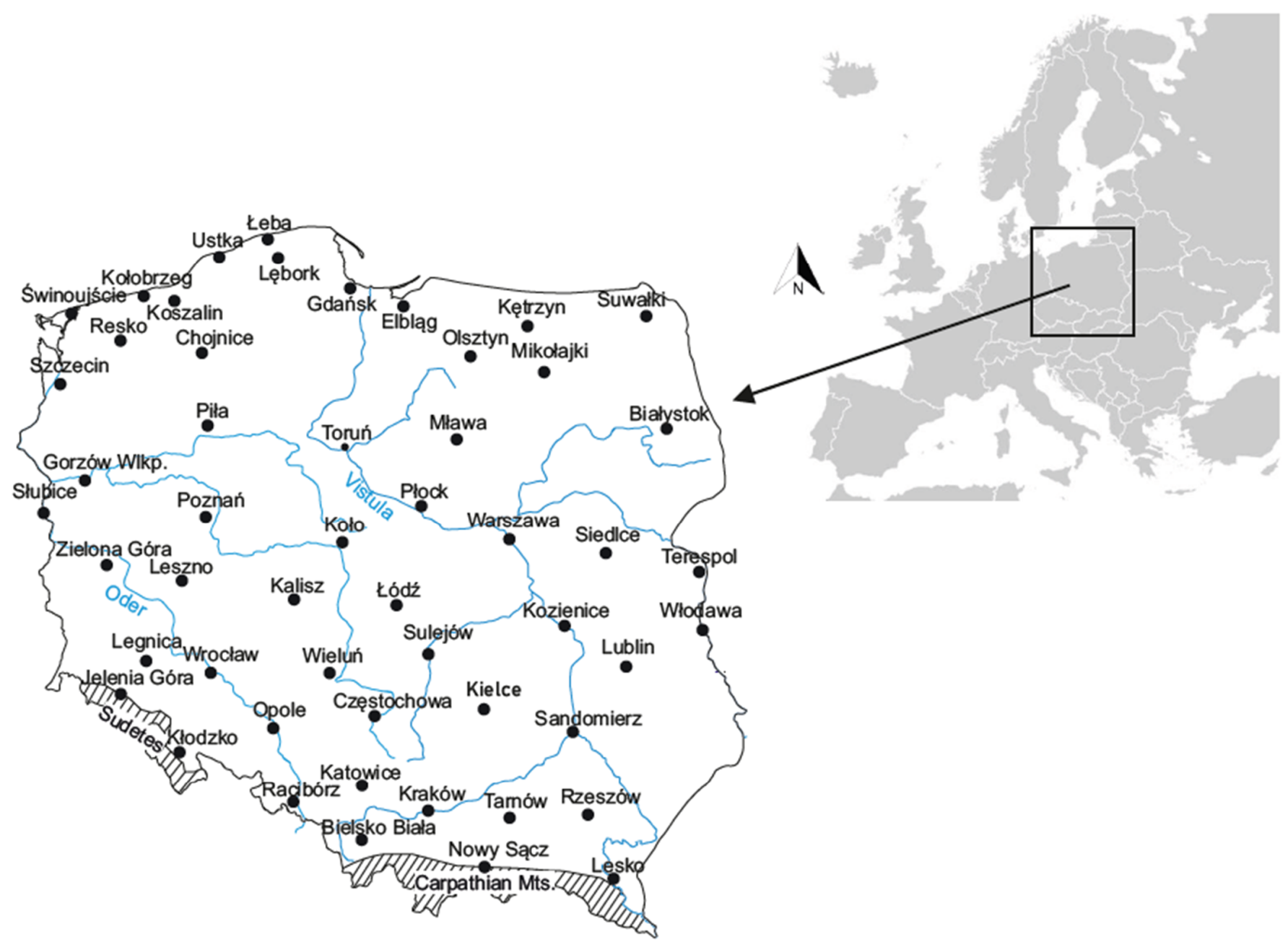

- IMGW-PIB stations VIIIIS area excluded from analysis

Figure 1. Location of meteorological stations in Poland.

A day with frosts was identified when the minimum air temperature was below $0.0^{\circ} \mathrm{C}$, and mean 24-h period air temperature was above $0.0^{\circ} \mathrm{C}$ [1].

Frosts constitute one of the greatest threats to plans in the growing season. Therefore, in the present paper, the phenomenon of ground frosts was analysed in the thermal growing season. The first stage of the research was to determine, using the method by Gumiński [59], the dates of the beginning and end of the period with air temperature above $5{ }^{\circ} \mathrm{C}$ in consecutive years, followed by establishing the date of the end of spring frosts occurrence and the beginning of the occurrence of autumn frosts. 
Mathematical formula by Gumiński [59] for the rising (1) and falling (2) phase of the mean temperature were utilized:

$$
\begin{aligned}
& \mathrm{x}_{1}=\frac{\mathrm{t}_{\mathrm{p}}-\mathrm{t}_{1}}{\mathrm{t}_{2}-\mathrm{t}_{1}} \mathrm{n} \\
& \mathrm{x}_{2}=\frac{\mathrm{t}_{1}-\mathrm{t}_{\mathrm{p}}}{\mathrm{t}_{1}-\mathrm{t}_{2}} \mathrm{n}
\end{aligned}
$$

where:

$t_{p}$-threshold value,

$t_{1}$-monthly mean temperature in the month preceding the crossing of the threshold value,

$t_{2}$-monthly mean temperature in the following month having exceeded the threshold value,

$\mathrm{n}$-number of days in the previous month,

$\mathrm{x}_{1}, \mathrm{x}_{2}$-number of days to be added to the 15th day of the previous month.

The next stage was to calculate the days with spring and autumn frosts and the duration (in days) of frost-free periods. Variability of the dates of occurrence of the last spring and the earliest autumn ground frosts, as well as the duration of frost-free area in Poland, were determined with the use of regression coefficients of the fitted linear trends, and the number of days per 10 years was given.

Considering the minimum air temperature values, the frosts were classified regarding their intensity, into four groups: from $-0.1^{\circ} \mathrm{C}$ to $-2.0^{\circ} \mathrm{C}$ (slight frosts), from $-2.1^{\circ} \mathrm{C}$ to $-4.0^{\circ} \mathrm{C}$ (moderate), from $-4.1^{\circ} \mathrm{C}$ do $-6.0^{\circ} \mathrm{C}$ (severe) and below $-6.0^{\circ} \mathrm{C}$ (very severe).

Mountain areas over $500 \mathrm{~m}$ above sea level were excluded from the study as, generally, plants with high thermal requirements are not cultivated there. Owing to great spatial and temporal discontinuity of frosts occurrence, the data collected from 52 meteorological stations allow only a general characteristics of this phenomenon in Poland.

To illustrate the temporal and spatial variability of frosts when characterising the particular features of frosts, apart from the averaged values for the whole country, figures (Figures 2, 4, 6, 8, 12 and 13) and Table 1 regarding the exemplary stations representative for different regions of the country were added (Figure 1).

\section{Results and Discussion}

In the climatic conditions of Poland, continuous occurrence of mean 24-h period air temperature above $5{ }^{\circ} \mathrm{C}$ is adopted as the beginning of the thermal growing season in spring and its end in autumn [32,34,35]. In the analysed multiannual period of 1971-2020, increasingly earlier dates of the beginning of the growing season in spring are observedfrom 3.0 days in Białystok to 3.4 days over 10 years in Wrocław, and in the scale of the whole country on average by 2.9 days (Figure 2). In turn, in autumn the extension of this period is observed from 2.2 days in Białystok to 4.5 days over 10 years in Wrocław, however for the whole country the extension is, on average, by 3.3 days. Consequently, the increased duration of the thermal growing season is pronounced, from 5.2 to 7.9 days and for the whole country, on average, by 6.1 days over 10 years (Figure 2). Polish literature on the subject analyses the variability of the number of days with ground frosts on a calendar basis, for example from April to October. As is presented in Figure 2, the course of the average number of days with the phenomenon under study shows a negative highly statistically significant trend. A similar course of the number of days with frosts was recorded in the area of Bydgoszcz in the period 1971-2020 [11], in the Wielkopolska Lowland in the years 1981-2010 [8] and in the Mazurskie Lakeland in the years 1966-2005 [30]. However, the number of days with frosts in the thermal growing season $\left(\mathrm{AT}>5^{\circ} \mathrm{C}\right)$ reflecting the actual risk to plants indicates that the analysed phenomenon does not show statistically significant temporal variability in the analysed 50-year long period (Figure 3). The duration of the growing season is clearly variable, from the shortest in Suwałki (203 days) to the longest in Stubice (245 days). The structure of the occurrence of the growing season on consecutive days in a year, together with its earliest and latest occurrence, is illustrated for 
selected stations in Figure 4. As illustrated, in some stations (Szczecin, Kołobrzeg) there were years in which a decrease in temperature marking the end of the growing season was recorded as late as in January of the next year. The increased frequency of frosts is also in line with the dates of the beginning of the latest occurrence of the growing season in spring and its earliest occurrence in autumn. The maximum frequency of these frosts is recorded, predominantly, several days after the average date of the beginning of the thermal growing season in spring and, respectively, prior to average date of the end of the growing season in autumn (Figure 4). It is worth mentioning here, that in Poland, according to the Act on subsidies to crop and livestock insurance (of 7 July 2005 as amended) [60], loss or a complete destruction of crops is covered by insurance provided that spring frosts occur between 15 April to 30 June. As is discussed in popular specialist literature and in petitions submitted by farmers and gardeners [61-63] to the Minister of Agriculture, the date 15 April, stated in the definition of "spring frosts", is questioned as being no longer valid owing to the ongoing global warming and thus increased thermal resources and the trend of an earlier occurrence of the thermal growing season. Therefore, it seems all the more valid that the date of liability of the insurer for possible loss of crops due to frosts should take into account the thermal beginning of the growing season and the average date of frost occurrence in spring which vary depending on the region of Poland.
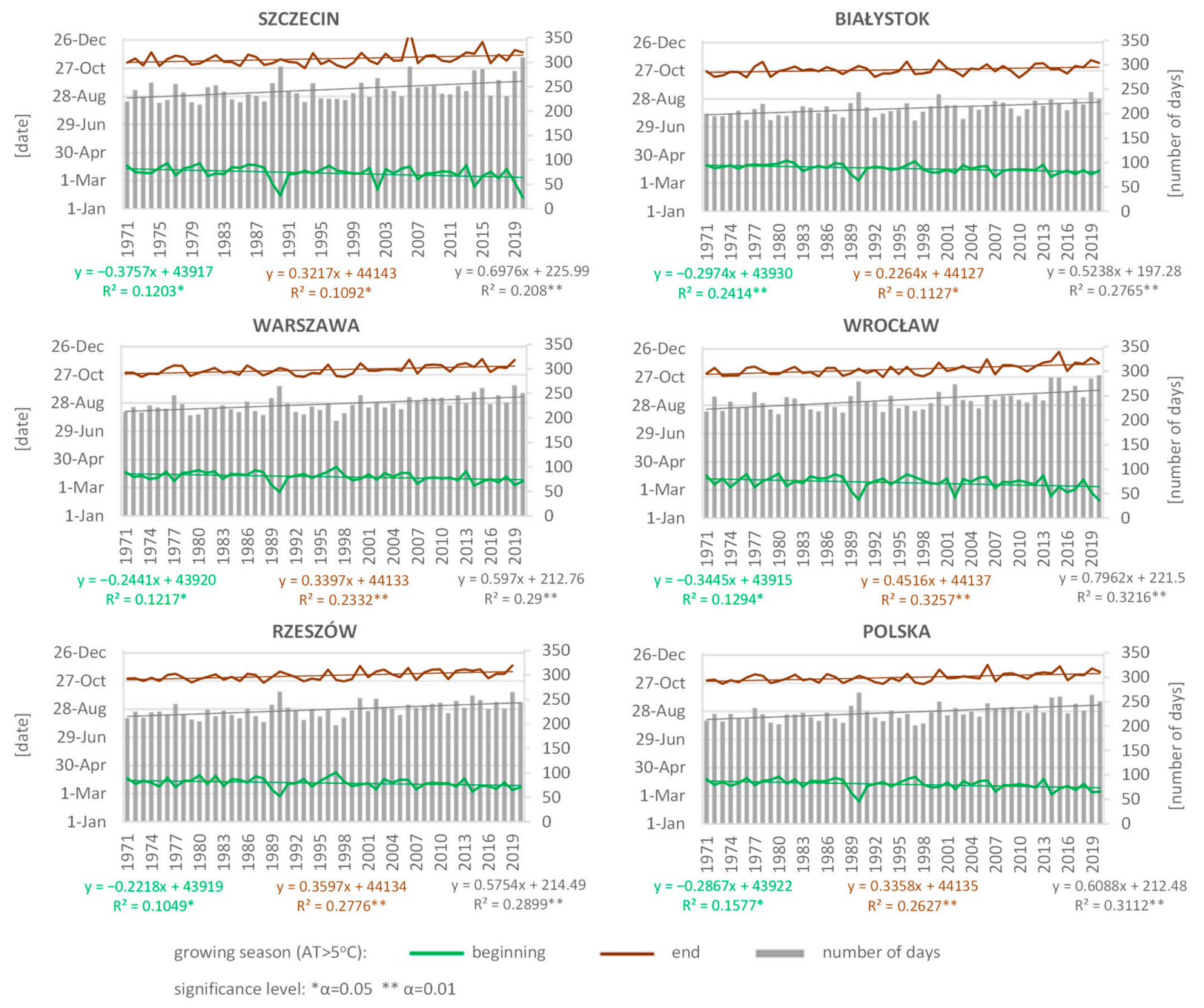

Figure 2. The dates of the beginning, end and duration of the growing season $\left(\mathrm{AT}>5^{\circ} \mathrm{C}\right)$ with the trend in Poland and in selected stations in the years 1971-2020. 


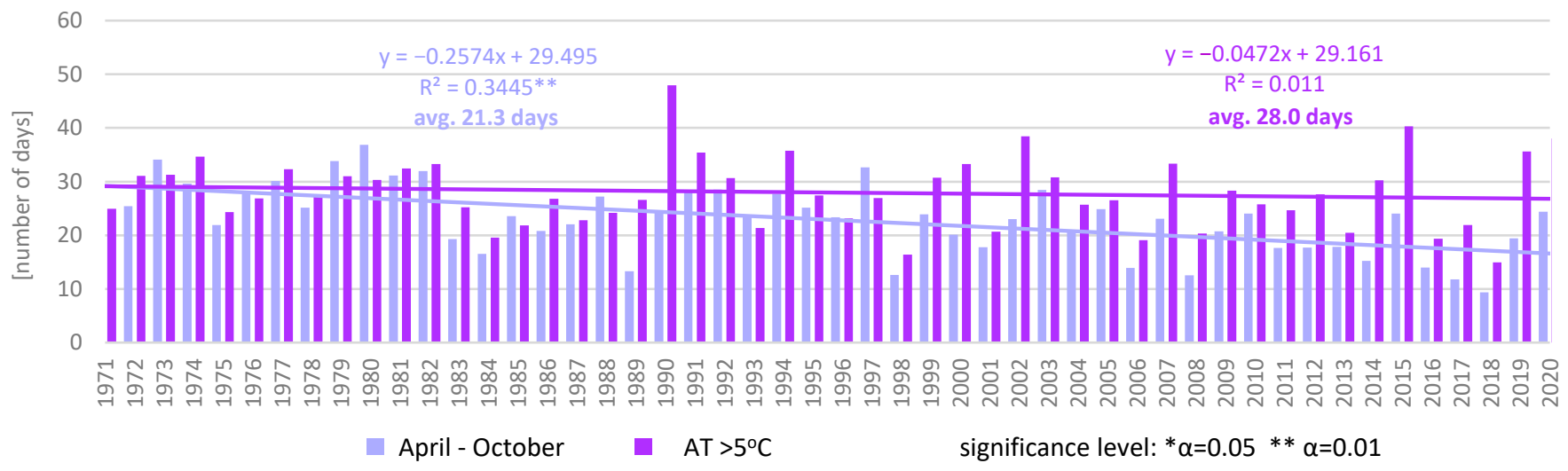

Figure 3. Average number of days with ground frosts in Poland in the period April-October and in the thermal growing season $\left(\mathrm{AT}>5^{\circ} \mathrm{C}\right)$ with the trend in the years 1971-2020.
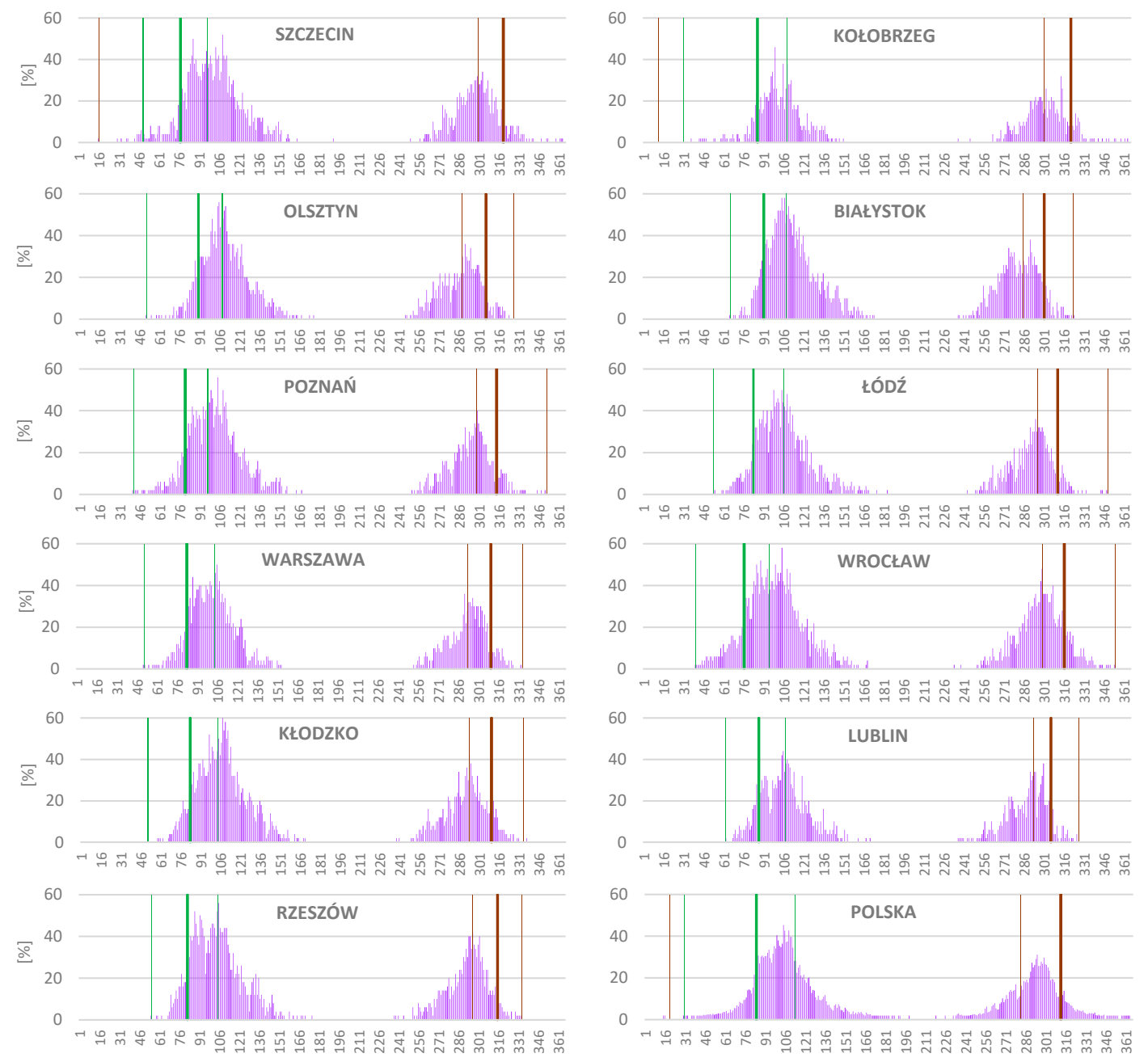

growing season $\left(\mathrm{AT}>5^{\circ} \mathrm{C}\right)$ : $\begin{aligned} & \text { average date : } \\ & \text { earliest/ latest date: } \quad \text { beginning }\end{aligned}$

Figure 4. Frequency (\%) of ground frosts occurrence on consecutive days in a year against (average, the earliest, the latest) dates of thermal growing season $\left(\mathrm{AT}>5^{\circ} \mathrm{C}\right.$ ) in Poland and in selected stations. Years 1971-2020. 
In spring, during the thermal growing season, throughout the country, ground frosts occur with the highest frequency in the second (14.3\%), first (12.4\%) ten-day period of April, and in autumn in the third (10.6\%) and in the second (7.7\%) ten-day period of October. Sporadically, air temperature below $0{ }^{\circ} \mathrm{C}$ at the ground level is recorded in consecutive decades of June: the first $-0.64 \%$, second $-0.23 \%$ and in the third only- $-0.05 \%$, and in the third decade of August $-0.11 \%$. Frosts in April constitute $36.6 \%$ of the total number of days with this phenomenon, an in October in autumn 23.2\%. The frosts in May posing risks to crops, known by farmers and often called "ice saints", occur with the duration of 2 days on the Coast, 2-4 days in the central area of the country and more than 4 days in the north-eastern part of Poland and at the Carpathian Foothills and the Sudetes Foreland (Table 1). Out of the 11 meteorological stations presented in Table 1, the highest number of days with frosts was recorded in the growing season in Wrocław-on average, 36.6 mainly due to an early occurrence of the beginning of the period observed there. This was followed by the station in Białystok-31.9 and in Kłodzko-31.4 days. Nationwide, the average number of days with spring frosts is almost twice as high as that recorded in the autumn season, and represents approx. $64 \%$ of the total number of days with this phenomenon. Similar results were obtained by Dragańska et al. [9] in the analysis of the frequency and intensity of frosts in north-east Poland.

Table 1. Average number of days with ground frosts in consecutive ten-day period of the growing season $\left(\mathrm{AT}>5^{\circ} \mathrm{C}\right)$ in selected stations in Poland. Years 1971-2020.

\begin{tabular}{|c|c|c|c|c|c|c|c|c|c|c|c|c|}
\hline & & $\begin{array}{l}Z \\
\text { Z } \\
\text { U } \\
\text { W } \\
\text { W }\end{array}$ & 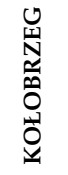 & 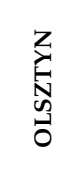 & 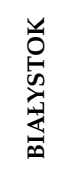 & $\begin{array}{l}\text { Z } \\
\text { Z } \\
\text { O } \\
\text { On }\end{array}$ & №̂ & 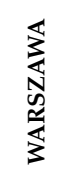 & 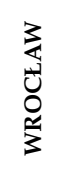 & 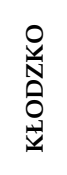 & 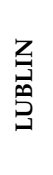 & 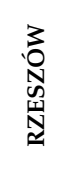 \\
\hline \multicolumn{13}{|c|}{ Dates of the beginning and end of the growing season $\left(\mathrm{AT}>5^{\circ} \mathrm{C}\right)$} \\
\hline 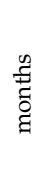 & 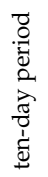 & $\begin{array}{l}\sqrt{x} \\
0 \\
= \\
\exists \\
\triangleq\end{array}$ & 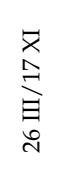 & 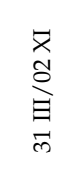 & 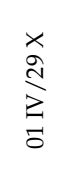 & 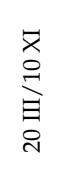 & 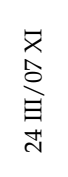 & 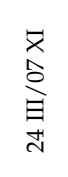 & 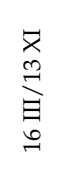 & 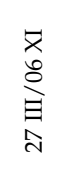 & 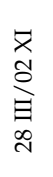 & 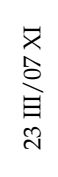 \\
\hline III & $\begin{array}{l}1 \\
2 \\
3\end{array}$ & $\begin{array}{l}1.4 \\
3.8\end{array}$ & 1.7 & 1.8 & & 3.6 & 2.9 & 2.9 & $\begin{array}{l}2.1 \\
4.3\end{array}$ & 2.9 & 2.2 & 3.9 \\
\hline IV & $\begin{array}{l}1 \\
2 \\
3 \\
\end{array}$ & $\begin{array}{l}3.8 \\
3.9 \\
2.8 \\
\end{array}$ & $\begin{array}{l}2.8 \\
2.5 \\
1.8 \\
\end{array}$ & $\begin{array}{l}3.3 \\
4.7 \\
3.7 \\
\end{array}$ & $\begin{array}{l}3.7 \\
5.4 \\
4.2 \\
\end{array}$ & $\begin{array}{l}4.2 \\
4.3 \\
2.8 \\
\end{array}$ & $\begin{array}{l}3.8 \\
4.3 \\
2.9 \\
\end{array}$ & $\begin{array}{l}3.9 \\
4.0 \\
2.5 \\
\end{array}$ & $\begin{array}{l}4.3 \\
4.3 \\
2.8 \\
\end{array}$ & $\begin{array}{l}4.0 \\
4.9 \\
3.7 \\
\end{array}$ & $\begin{array}{l}2.8 \\
3.6 \\
2.5 \\
\end{array}$ & $\begin{array}{l}4.1 \\
4.6 \\
3.1 \\
\end{array}$ \\
\hline $\mathrm{V}$ & $\begin{array}{l}1 \\
2 \\
3\end{array}$ & $\begin{array}{l}1.4 \\
1.1 \\
0.6\end{array}$ & $\begin{array}{l}0.8 \\
0.5 \\
0.1\end{array}$ & $\begin{array}{l}2.2 \\
1.4 \\
0.7\end{array}$ & $\begin{array}{l}2.5 \\
1.6 \\
1.2\end{array}$ & $\begin{array}{l}1.6 \\
0.9 \\
0.6\end{array}$ & $\begin{array}{l}1.6 \\
1.0 \\
0.6\end{array}$ & $\begin{array}{l}1.3 \\
0.5 \\
0.4\end{array}$ & $\begin{array}{l}1.6 \\
1.0 \\
0.6\end{array}$ & $\begin{array}{l}2.1 \\
1.5 \\
0.7\end{array}$ & $\begin{array}{l}1.4 \\
0.7 \\
0.5\end{array}$ & $\begin{array}{l}1.5 \\
1.4 \\
0.5\end{array}$ \\
\hline VI & $\begin{array}{l}1 \\
2 \\
3 \\
\end{array}$ & $\begin{array}{c}0.2 \\
0.0^{*}\end{array}$ & & $\begin{array}{c}0.3 \\
0.1 \\
0.0^{*}\end{array}$ & $\begin{array}{c}0.5 \\
0.2 \\
0.0 \text { * }\end{array}$ & $\begin{array}{c}0.2 \\
0.0^{*}\end{array}$ & $\begin{array}{c}0.3 \\
0.2 \\
0.0^{*}\end{array}$ & 0.1 & $\begin{array}{l}0.3 \\
0.1\end{array}$ & $\begin{array}{l}0.2 \\
0.1\end{array}$ & $\begin{array}{l}0.1 \\
0.1\end{array}$ & $\begin{array}{c}0.2 \\
0.1 \\
0.0 \text { * }\end{array}$ \\
\hline VII & $\begin{array}{l}1 \\
2 \\
3\end{array}$ & & & & & & & & & & & \\
\hline VIII & $\begin{array}{l}1 \\
2 \\
3\end{array}$ & & $0.0^{*}$ & & 0.1 & & & & 0.0 * & $0.0^{*}$ & 0.1 & 0.1 \\
\hline IX & $\begin{array}{l}1 \\
2 \\
3\end{array}$ & $\begin{array}{c}0.0^{*} \\
0.2 \\
0.4\end{array}$ & $\begin{array}{c}0.0^{*} \\
0.0^{*} \\
0.2\end{array}$ & $\begin{array}{l}0.1 \\
0.7 \\
1.2\end{array}$ & $\begin{array}{l}0.3 \\
1.1 \\
2.0\end{array}$ & $\begin{array}{c}0.0^{*} \\
0.4 \\
0.6\end{array}$ & $\begin{array}{l}0.1 \\
0.6 \\
0.7\end{array}$ & $\begin{array}{c}0.0^{*} \\
0.4 \\
0.7\end{array}$ & $\begin{array}{l}0.1 \\
0.4 \\
0.6\end{array}$ & $\begin{array}{l}0.1 \\
0.6 \\
0.9\end{array}$ & $\begin{array}{l}0.2 \\
0.5 \\
0.8\end{array}$ & $\begin{array}{l}0.1 \\
0.5 \\
0.9\end{array}$ \\
\hline$X$ & $\begin{array}{l}1 \\
2 \\
3\end{array}$ & $\begin{array}{l}1.1 \\
2.0 \\
3.2\end{array}$ & $\begin{array}{l}0.6 \\
1.3 \\
2.1\end{array}$ & $\begin{array}{l}1.7 \\
2.5 \\
2.6\end{array}$ & $\begin{array}{l}2.8 \\
2.8 \\
2.2\end{array}$ & $\begin{array}{l}1.3 \\
2.3 \\
3.4\end{array}$ & $\begin{array}{l}1.4 \\
2.3 \\
3.2\end{array}$ & $\begin{array}{l}1.3 \\
2.2 \\
3.1\end{array}$ & $\begin{array}{l}1.4 \\
2.6 \\
4.0\end{array}$ & $\begin{array}{l}1.5 \\
2.7 \\
2.9\end{array}$ & $\begin{array}{l}1.7 \\
2.4 \\
2.7\end{array}$ & $\begin{array}{l}1.5 \\
2.5 \\
3.9\end{array}$ \\
\hline XI & $\begin{array}{l}1 \\
2 \\
3\end{array}$ & $\begin{array}{l}2.1 \\
0.9\end{array}$ & $\begin{array}{l}1.9 \\
1.0\end{array}$ & 0.8 & & 1.7 & 1.2 & 1.4 & $\begin{array}{l}2.8 \\
1.5\end{array}$ & 1.6 & 0.9 & 1.7 \\
\hline
\end{tabular}

${ }^{*}$ value in the range $0.02-0.04$ day ( 1 or 2 days over 50 years). 
In spring, the analysed ground frosts disappear the earliest on the Coast and along the upper section of the Wisła river valley (to Sandomierz), on average before 5 May, and the latest-after 25 May, in the area of Łeba and Lebork and in the north-eastern part of the country (Figure 5a). Relatively early, on average between 5 May and 10 May, frosts disappear in the south-western part of the country, in the coastal zone and around Mamry and Śniardwy Lakes. In turn, in the central part of Poland, frosts disappear between 10 May and 15 May, and in both Lakelands and in the Lublin Upland between 15 May and 20 May. The course of the isarithm of the value 15 May divides the country into two parts of almost equal size: the north-east and south-west (Figure 5a).
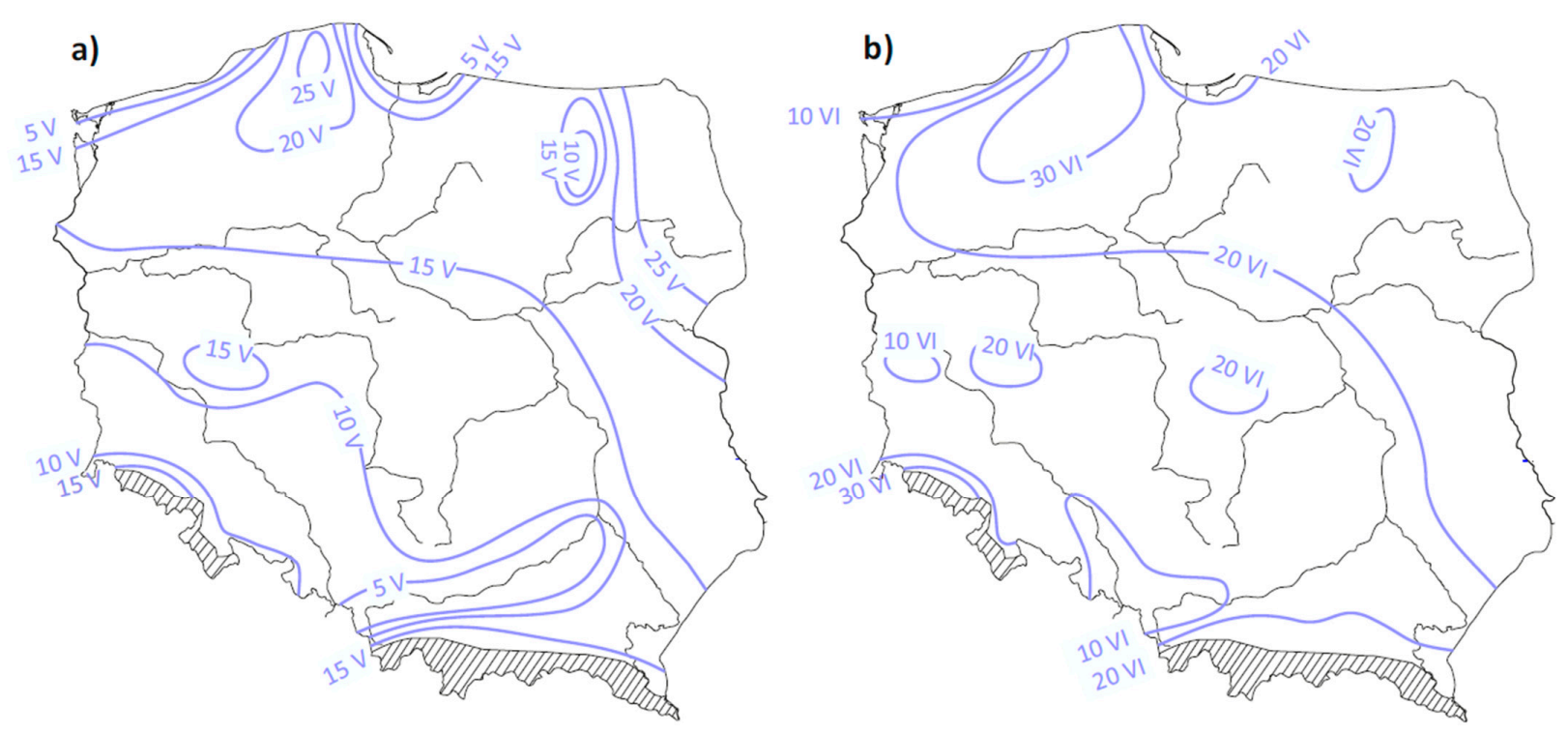

Figure 5. Average (a) and the latest $(\mathbf{b})$ dates of occurrence of the latest spring ground frosts $\left(\mathrm{AT}_{\min }<0.0^{\circ} \mathrm{C}\right)$ in Poland. Years 1971-2020.

A great risk to thermophilic plants $\left(\mathrm{AT}>10^{\circ} \mathrm{C}\right.$ ) in spring is caused by ground frosts occurring very late. The isarithm of 20 June divides the country into two parts: the northeast, where the latest frosts can occur even till the end of June, and the south-west where the frosts with the latest day of occurrence are recorded between 10 June and 20 June (Figure 5b). The earliest date of disappearance of frosts, before $10 \mathrm{June}$, is recorded on the Coast and in the upper sections of the Odra and Wisła rivers to which, through the Moravian Gate, warm air masses often flow in spring. As a result of the ongoing global warming, the disappearance of frosts is recorded at an increasingly earlier dates in spring, and the occurrence of frosts in autumn is recorded at increasingly later dates, as is presented in Figures 6 and 7. The values of the regression coefficients show that from the north-east to south-west of Poland, the rate of disappearance of the analysed frosts increases from 0.3 day in Białystok to more than 4 days in the central basin of the Odra and Wisła river, and for the whole area of Poland on average by 2.8 days over 10 years. In turn, in autumn the dates of occurrence of frosts is recorded later, from 2.0 days in the central eastern part of Poland to 3.0 days in the Lubuskie Lakeland, and in Pomorskie Lakeland as many as by 2.0 to 5.0 days later, for the whole area of Poland the average is 3.0 days over 10 years. Importantly, the directions of changes discussed above were found to be statistically significant for most of the stations. The trend of the variable dates of the occurrence of the last spring and earliest autumn frosts was indicated by Dragańska et al. [9], Bielec-Bąkowska and Piotrowicz [10], Tomczyk [8], Koźmiński and Michalska [21]. 

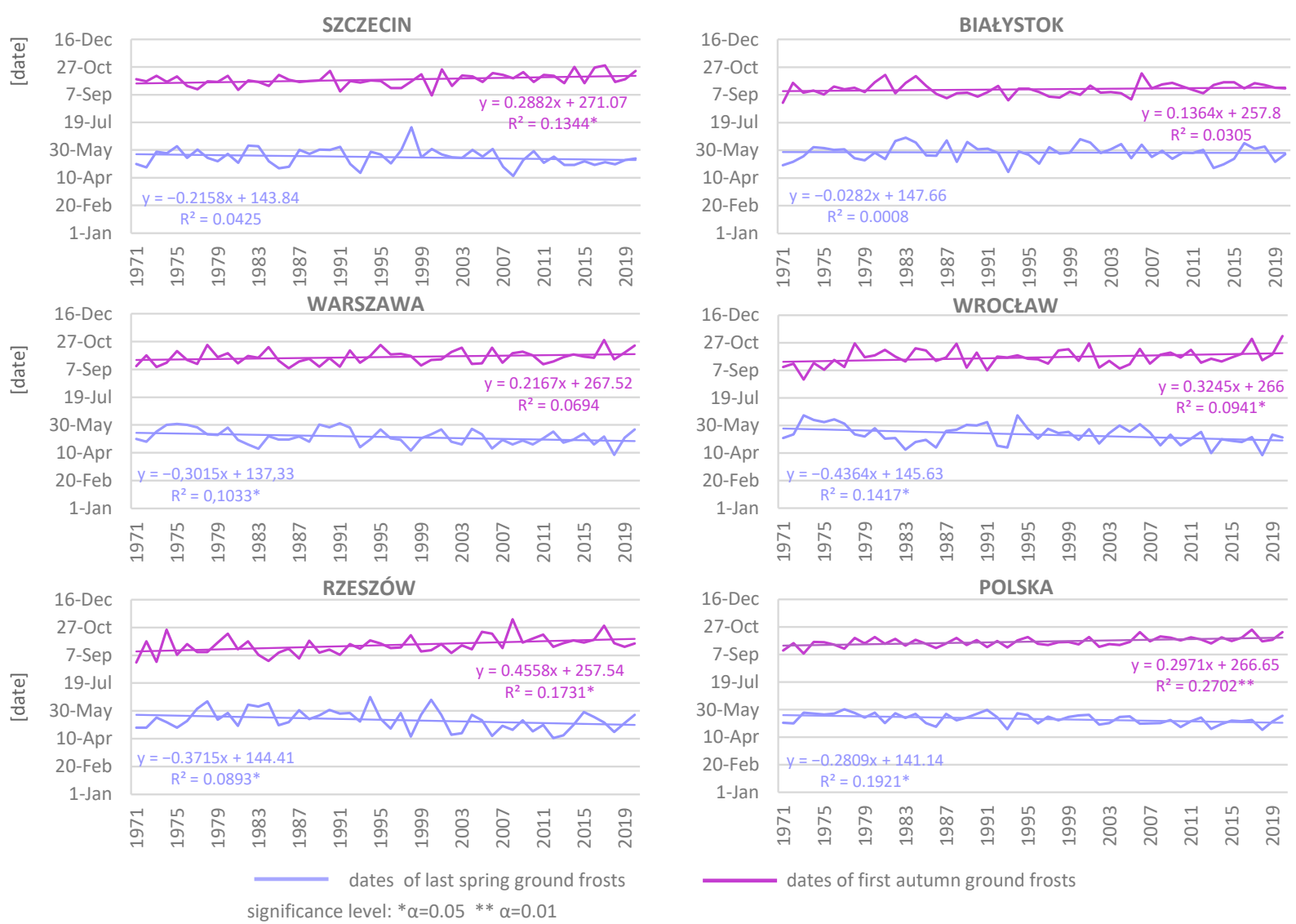

Figure 6. Dates of the last spring and the beginning of the autumn ground frosts together with the trend for Poland and in selected stations in the years 1971-2020.
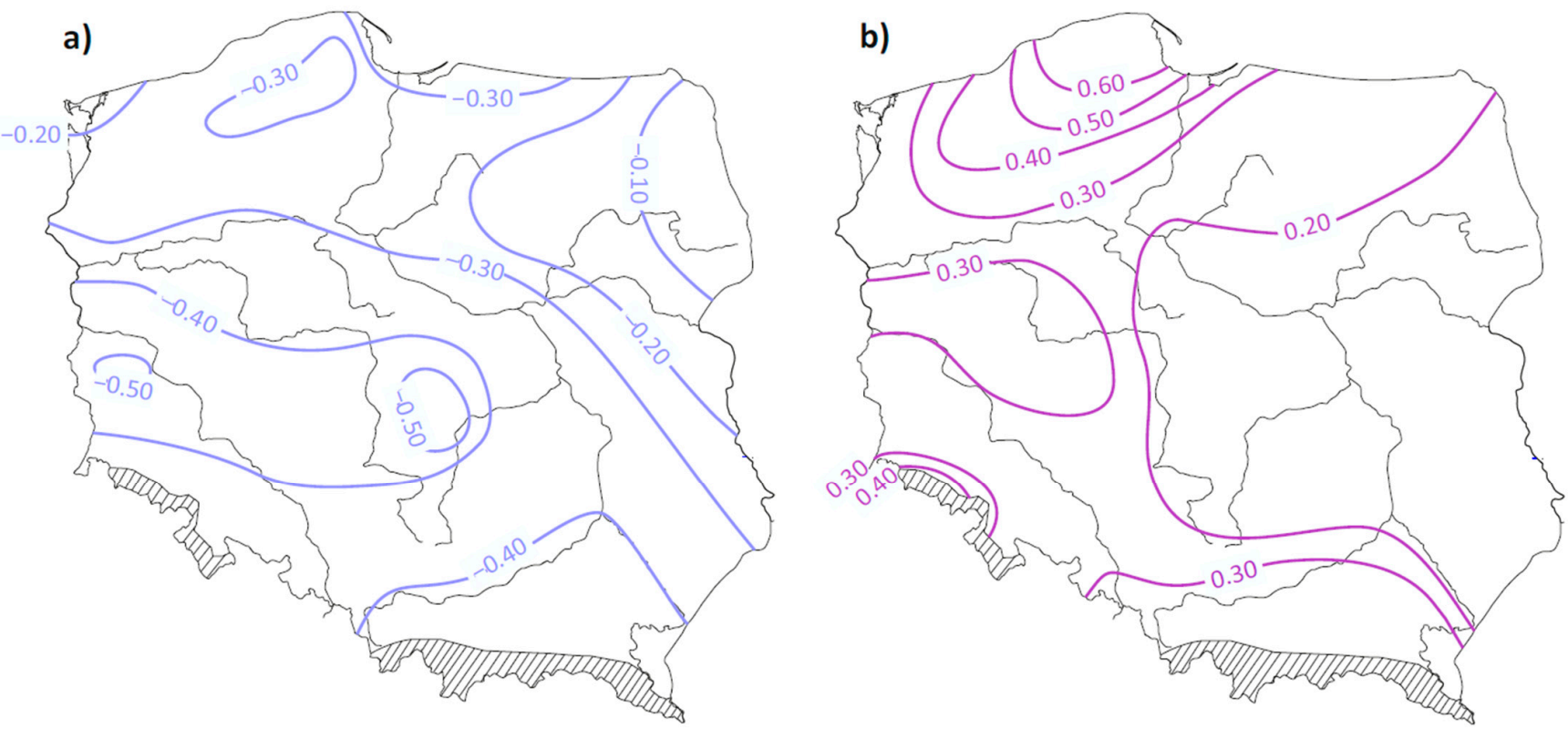

Figure 7. Values of regression coefficients for average dates of the last spring (a) and the first autumn (b) ground frosts $\left(\mathrm{AT}_{\min }<0.0^{\circ} \mathrm{C}\right)$ in Poland. Years 1971-2020. 
The tendency of an earlier disappearance of ground frosts in spring and later occurrence in autumn was also observed with respect to ground frosts of higher intensity (Figure 8). For example, in spring, ground frosts of the intensity $<-2.0^{\circ} \mathrm{C}$-disappear earlier by 1.2 day over 10 years in Białystok and 1.8 day in Warszawa-to 5.2 days in Wrocław, and ground frosts of the intensity $<-4.0^{\circ} \mathrm{C}$-from 1.1 day in Białystok to 5.8 days in Kraków. There are years in which spring frosts of the intensity $<-4.0^{\circ} \mathrm{C}$ are not recorded, as was the case in the years: 1983, 2000, 2004, 2009 and 2010 in Kraków and in 2013 in Białystok (Figure 8). In turn, in autumn, frosts of the intensity $\mathrm{AT}_{\min }<-2{ }^{\circ} \mathrm{C}$ occur at a later date by 0.6 day over 10 years in the area of Szczecin to 3.5 days in Wrocław, and frosts of the intensity $<-4.0^{\circ} \mathrm{C}$ from 1.3 day in Białystok to 5.3 days in Kraków, which is similar to the situation in spring.
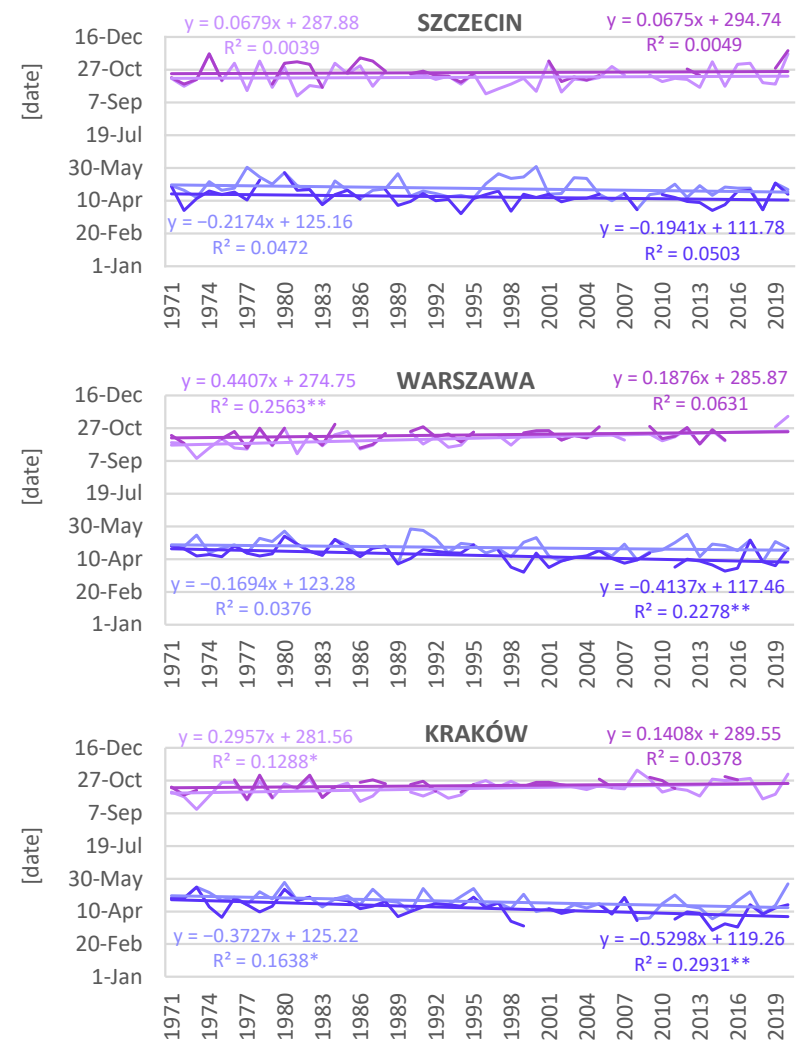

$\mathrm{AT}_{\min }$ below: $-2^{\circ} \mathrm{C}\left[\bar{L}_{\text {significance level: }{ }^{*} \alpha=0.05 * *} \alpha=0.01\right.$
$-4^{\circ} \mathrm{C}[\overline{-}$
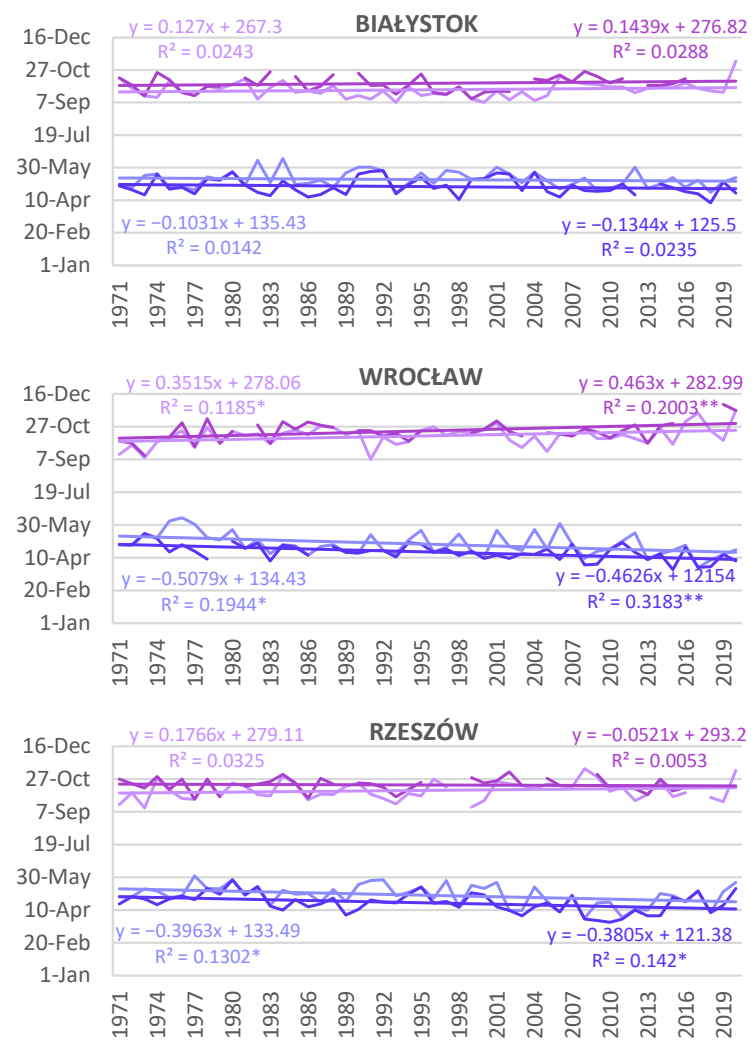

spring ground frosts autumn ground frosts

Figure 8. Dates of occurrence of the last spring ground frosts and the beginning of autumn ground frosts according to intensity together with the trend in selected stations in Poland in the period 1971-2020.

According to Figure 9, the longitudinal orientation of isarithm of the average dates of occurrence of the first ground frosts evidently represents the advent of autumn from the east to the west of Poland. The earliest occurrence, on average before 20 September, is recorded in the Biebrza River Basin and in the Białostocka Upland, and the latest date of occurrence, after 10 October, is recorded in the western part of the Coast. However, there are years in which the first occurrence of ground frosts is observed as early as 31 August, as was the case in the east of the country, in the Barycz river basin and in the higher parts of the Pomorskie Lakeland, or as late as after 15 September at the seaside (Figure 9b). The average dates of occurrence of the first autumn frosts presented in Figure 9 demonstrate close similarity to the spatial distribution of these dates given in the literature on the subject $[12,14,31]$. 

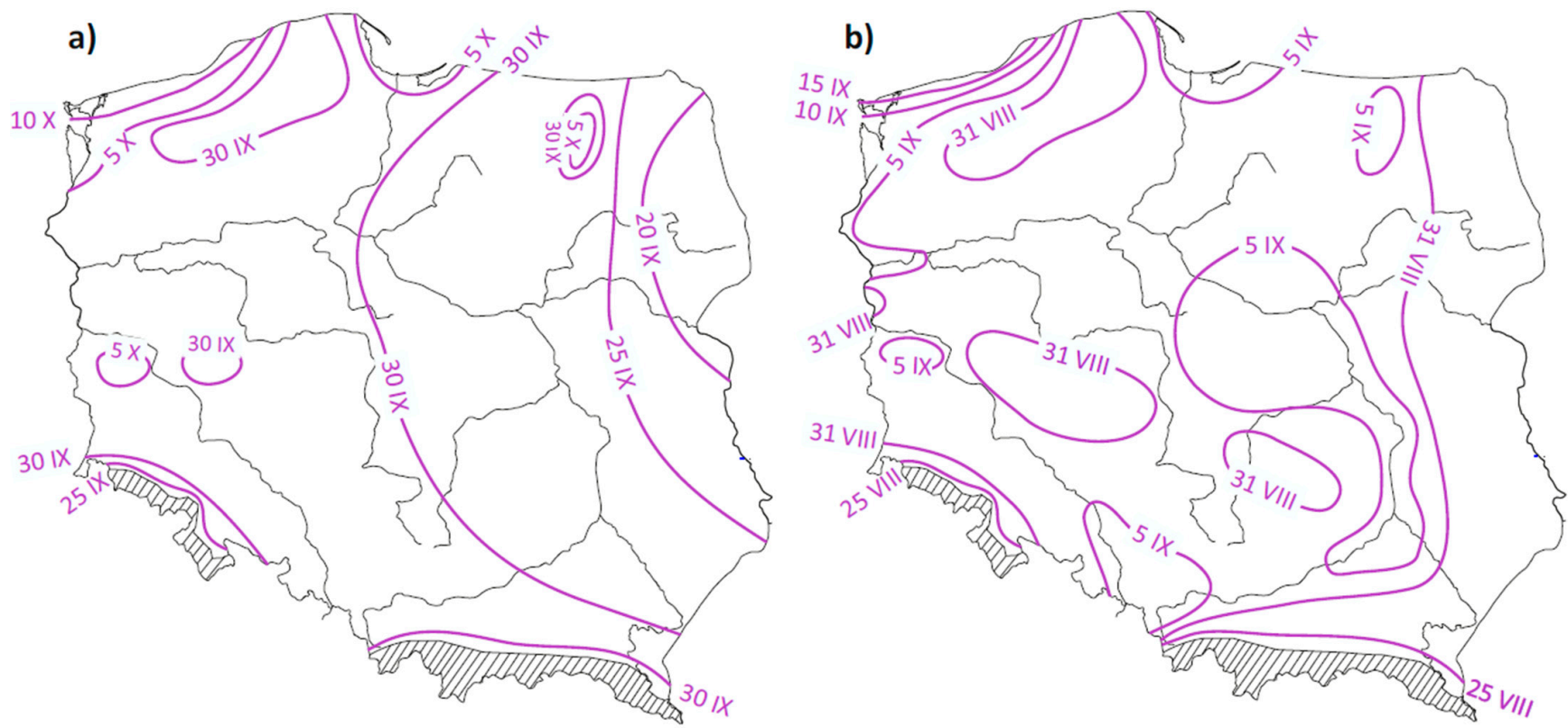

Figure 9. Average (a) and the earliest (b) dates of occurrence of the first autumn ground frosts $\left(\mathrm{AT}_{\min }<0.0^{\circ} \mathrm{C}\right)$ in Poland. Years 1971-2020.

A significant indicator characterising the phenomenon of frosts is the duration of the frost-free period. The duration is, on average, below 120 days in the north-eastern part of Poland and more than 150 days on the Coast (apart from the area of Łeba) and in the upper section of the Wisła River (Figure 10a). Significant variations in the duration of the frost-free period (120-140) is recorded to the east of the Wisła and San River valleys. The average duration for the whole area of Poland is 141 days. The calculated values of regression coefficients of the fitted linear trends (Figure 10b) manifest the increase in the duration of the frost-free period throughout most of the country, particularly due to an earlier disappearance of the last spring frosts, from 2.0 days in the north-east to 6.0 days over 10 years in the western part of Poland.
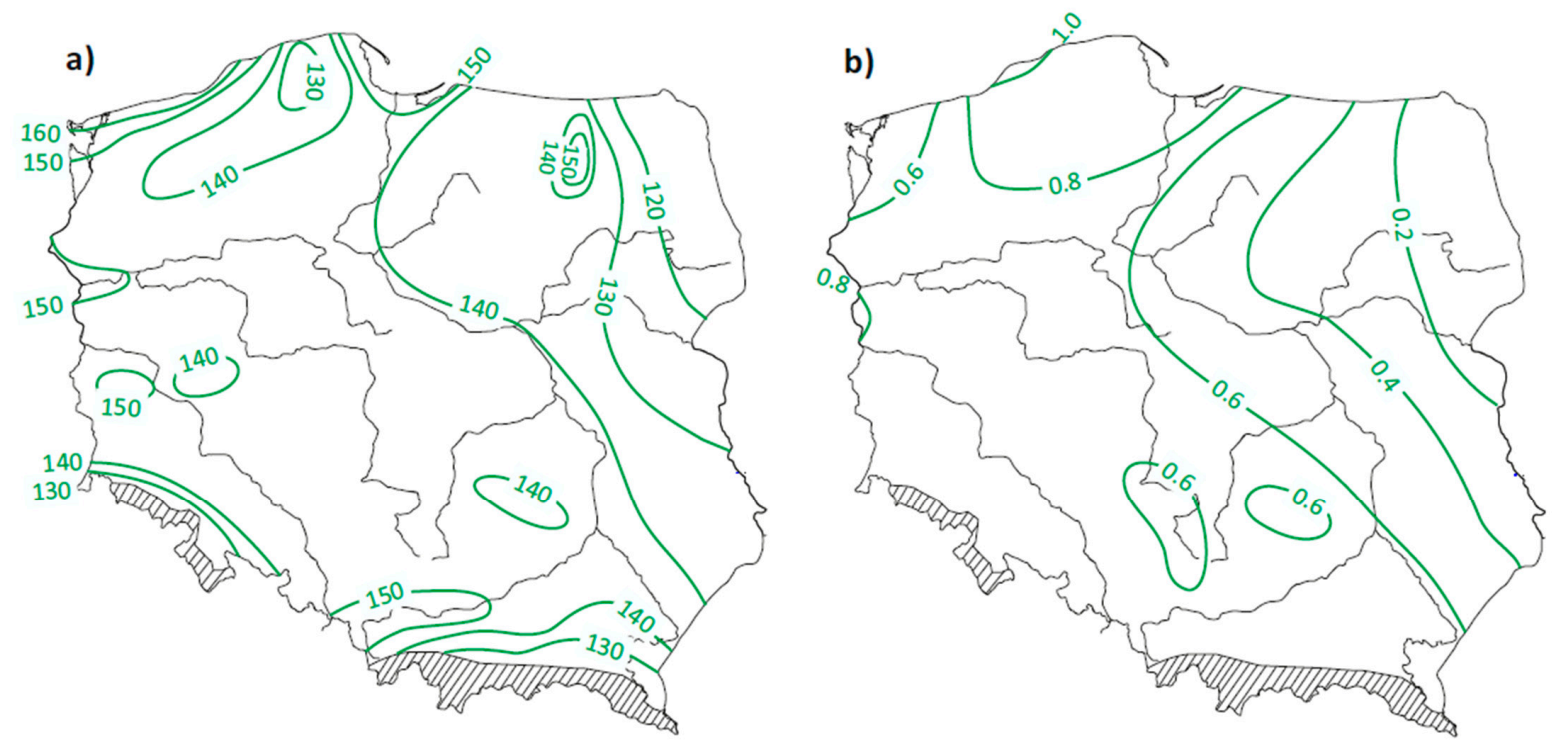

Figure 10. Average duration of the frost-free period per days (a) and the values of regression coefficients of the frost-free period (b) in Poland. Years 1971-2020. 
Another characteristic of frosts used in the description of the phenomenon is the number of days with frosts in spring and autumn. In the analysed period of 1971-2020, the average number of days with ground frosts in spring, calculated from the beginning of the thermal growing season $\left(\mathrm{AT}<5^{\circ} \mathrm{C}\right.$ ) is 17.5 days for the whole of the country and is the lowest in the coastal zone-less than 15.0 days, and the highest-more than 20.0 days, in the area of Białystok, along the Odra River, in the Carpathian Foothills and the Sudetes Foreland (Figure 11a). In autumn, the average number of days with ground frosts amounts to 10.3 for the whole area of Poland, and is by $41 \%$ lower than that in the spring season. In the north of Poland, on average, 8-10 days are recorded and in the central and southern part of the country from 10 to 12 days, in the Carpathian Foothills and the Sudetes Foreland even more than 14 days (Figure 11b).
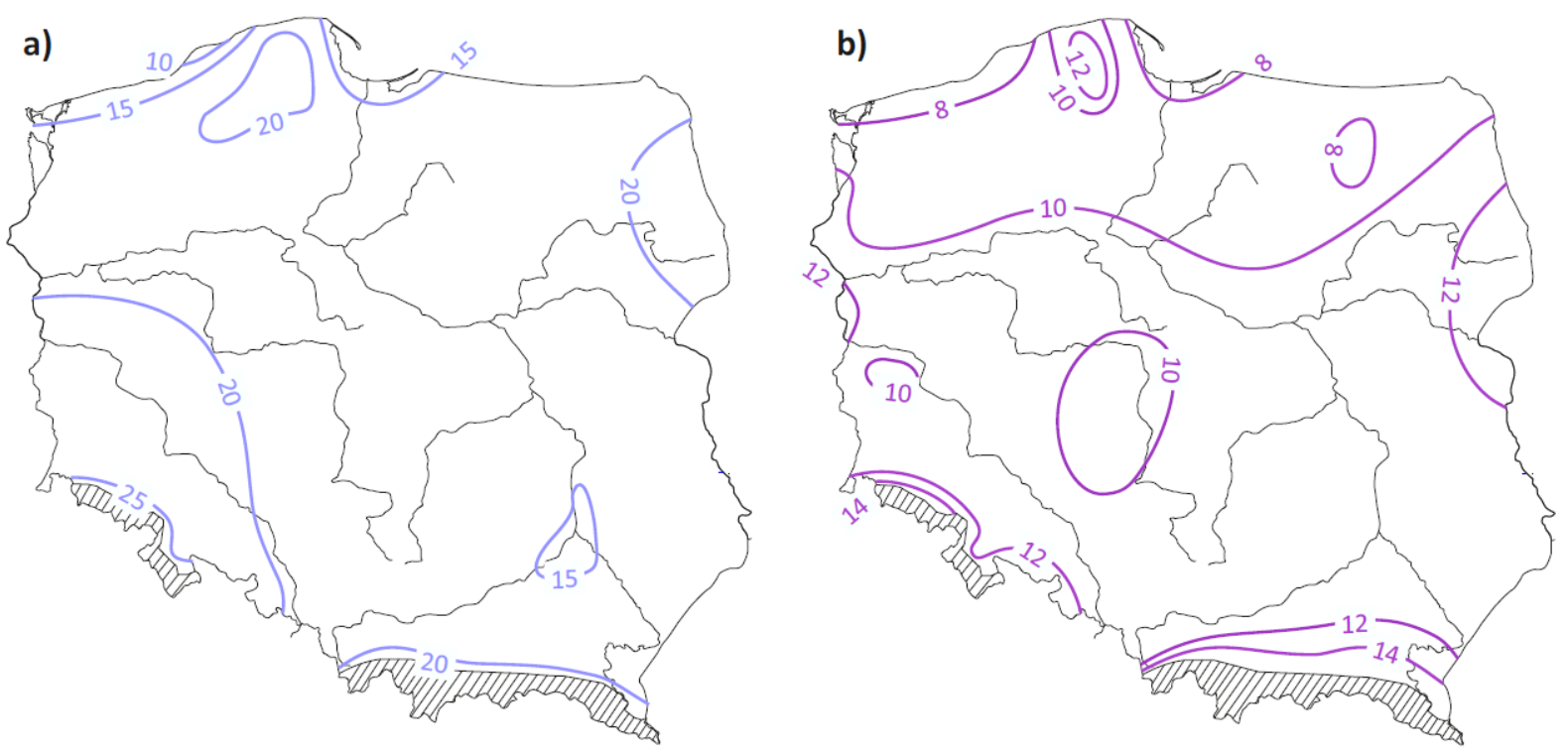

Figure 11. Average number days with ground frosts in spring (a) and autumn (b) in Poland. Years 1971-2020.

In the light of data presented in Figure 12, there is a high variability in the number of days with ground frosts in spring on a year-to-year basis. However, there are periods lasting a few or several years during which there is an increase as well as a decrease in the frequency of occurrence. Such high inter-annual variability partly explains the lack of a statistically significant trend of the number of days in most stations (with the exception of six stations-positive trend: Suwałki, Terespol; negative trend: Elblag, Kraków, Sandomierz, Zielona Góra). At best, it is possible to distinguish the occurrence of a slight tendency in spring of an increase in the number of days with frost in the north-west and north-east of Poland, and the respective decrease in the central and southern part of Poland. Frosts of the intensity $<-4{ }^{\circ} \mathrm{C}$ are most frequently recorded in years with a high number of frosts below $<0.0$ and $<-2.0^{\circ} \mathrm{C}$. Often, following the years with low frequency of ground frosts, a significant increase is recorded in the next year (Figure 12). In comparison to spring, during the thermal growing season in autumn, the number of days with frosts is markedly lower, though in this season there is also a trend of a slight increase as well as a decrease in the number of days with the phenomenon, interestingly in the same areas as in spring. However, similarly to spring, the observed direction of changes is statistically insignificant for most stations, as is confirmed by data presented in Figure 13. A positive feature of the climate of Poland is the fact that the increase in the number of days in a given area of the country, at a particular time, does not always translate into an increase in another area. The highest variability in the number of days with frosts of various intensity on a year-to-year basis is pronounced in the area of the coast from Świnoujście to Ustka, and the lowest in the area of Suwałki and Białystok (Figures 12 and 13). 

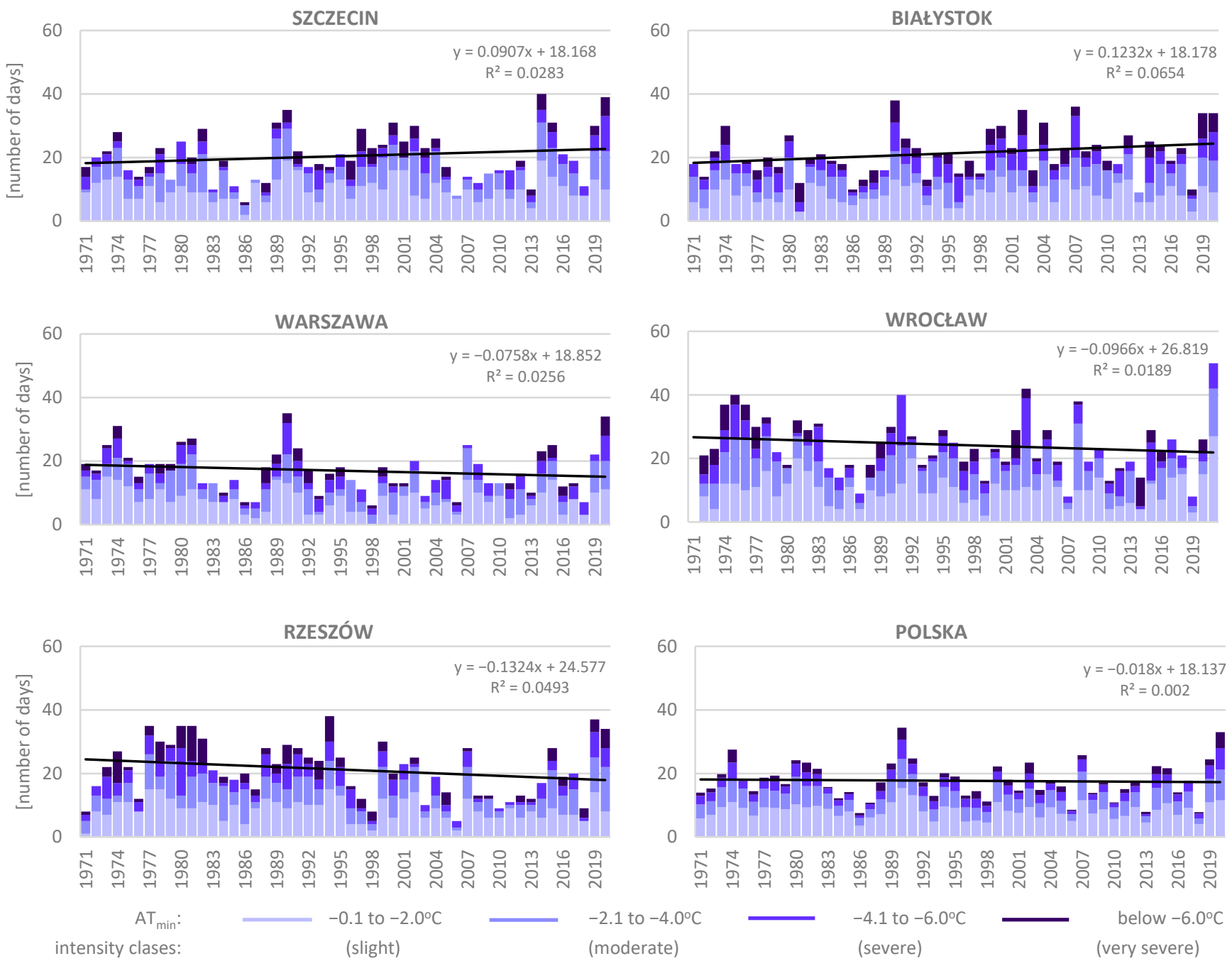

intensity clases:

(slight)

-2.1 to $-4.0^{\circ} \mathrm{C}$
(moderate)

(severe)

(very severe)

Figure 12. The number of days with ground frosts together with trend per intensity classes in spring in Poland and in selected stations in the period 1971-2020.

The percentage share of severe and very severe ground frosts in the total number of frosts allows the assessment of the intensity of the phenomenon in the growing season in individual meteorological stations located in different physiographic conditions (Figure 14). The stations located nearby water reservoirs, such as Świnoujście, Kołobrzeg, Ustka or Mikołajki are characterised by a small number of days with ground frosts in comparison to the neighbouring stations located farther from the reservoirs, which is particularly manifested in autumn. The share of severe and very severe spring frosts in their total number amounts to $7.8 \%$ in Kołobrzeg, $15.3 \%$ in the neighbouring city of Koszalin (Figure 14). Small percentage share of the frosts is also recorded in stations located nearby hill slopes, such as Zielona Góra, Sandomierz or Gorzów Wielkopolski. 

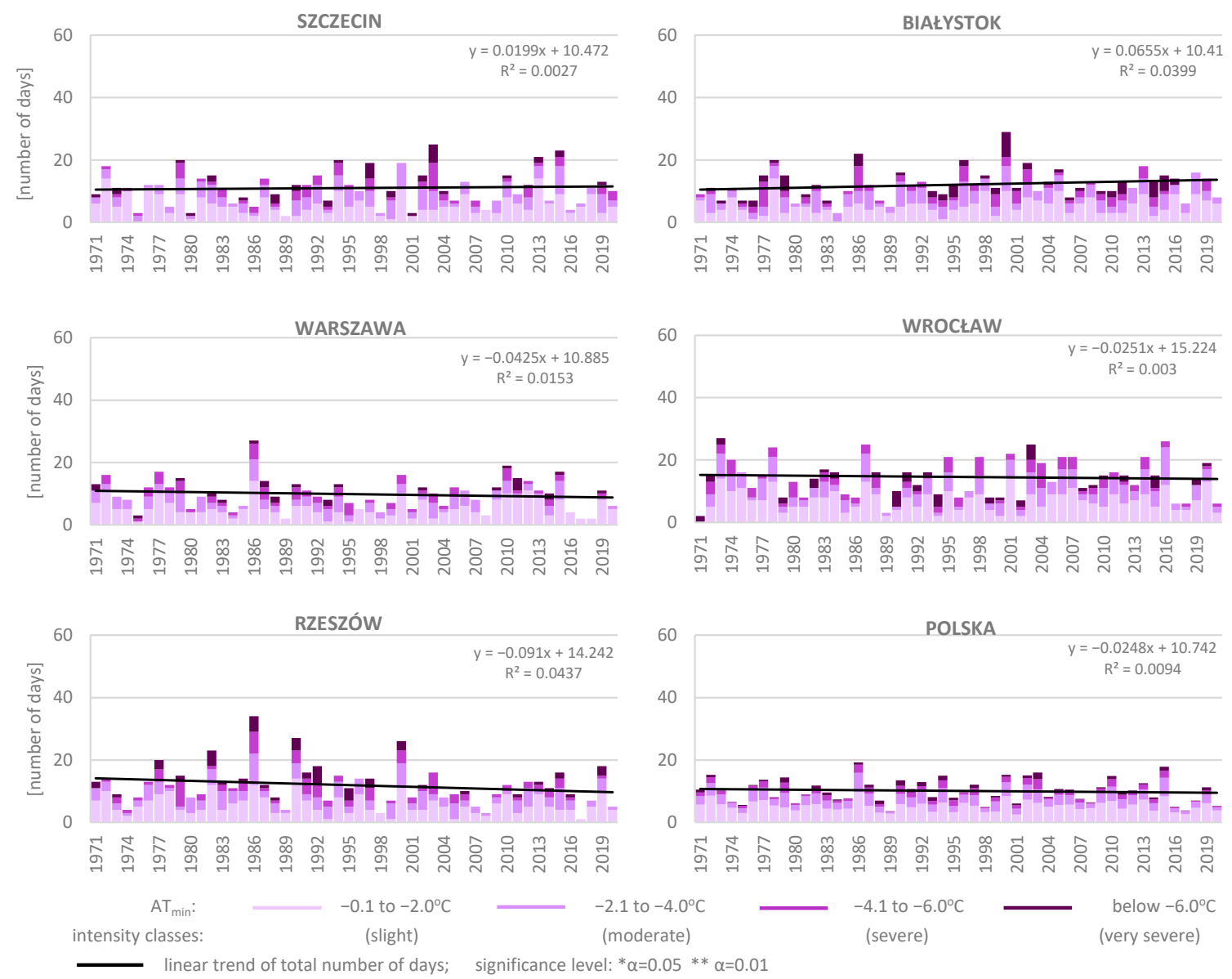

Figure 13. The number of days ground frosts together with a trend per intensity classes in autumn in Poland and in selected stations in the years 1971-2020.
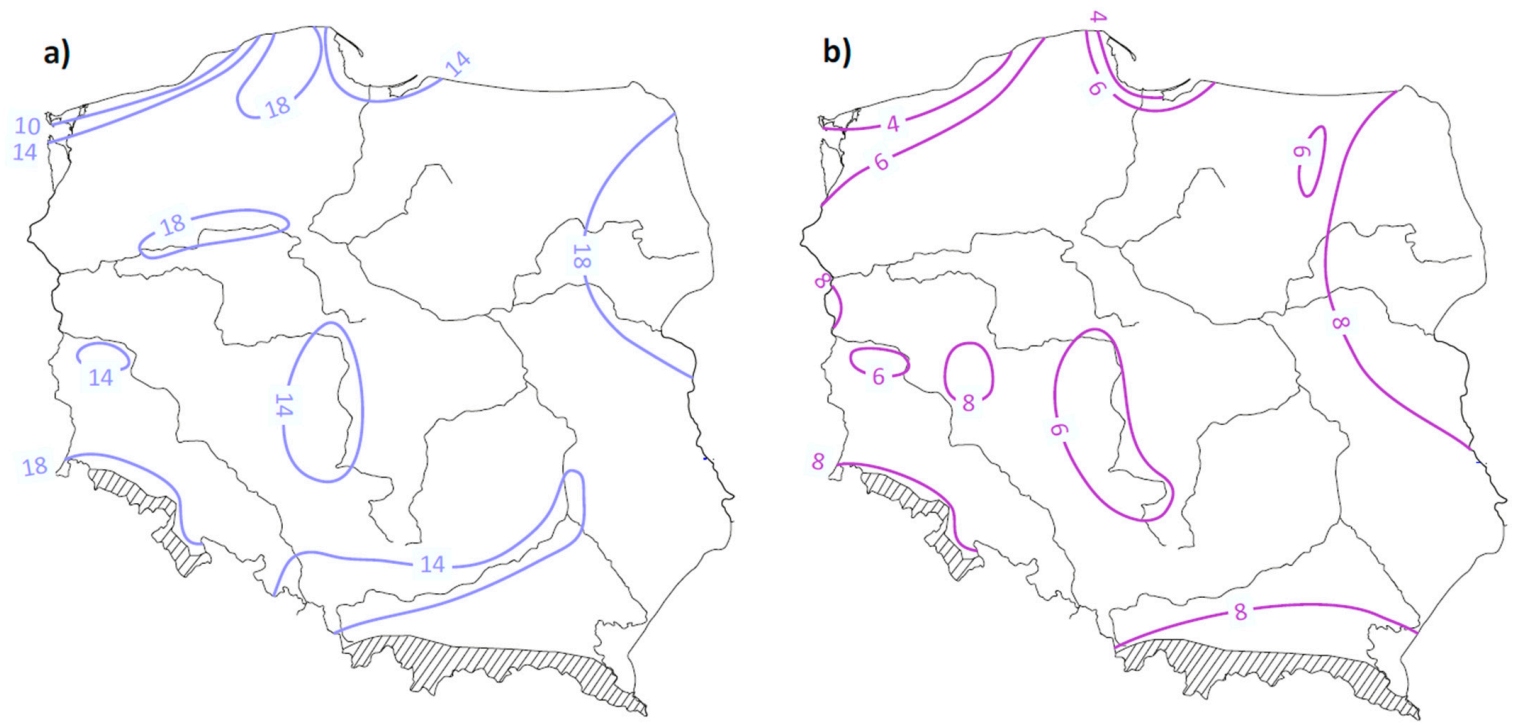

Figure 14. Percentage share of the number of days with severe $\left(\mathrm{AT}_{\min }-4.1\right.$ to $\left.-6.0^{\circ} \mathrm{C}\right)$ and very severe $\left(\mathrm{AT}_{\min }<-6.0{ }^{\circ} \mathrm{C}\right)$ ground frosts in their total number in spring (a) and autumn (b) in Poland. Years 1971-2020.

On a countrywide scale, the intensity of ground frosts in spring is greater than that recorded in autumn. In spring, the smallest number of severe and very severe frosts is 
recorded on the Coast-less than 10\%, and the highest-more than $18 \%$ in the Biebrza River basin and in the Białostocka Upland, in areas of Lebork, in the central and lower course of the river Noteć and on the Sudetes Foreland (Figure 14a). However, throughout most of the country, this share is from $14 \%$ to $18 \%$. Apart from the Coast, the privileged areas of reduced percentage share of days with severe and very severe ground frosts are the areas of: Kalisz and Wielun, Dolny Ślask and the upper section of the Wisła River to Sandomierz. In autumn, water reservoirs significantly reduce the number of days with frosts below $-4.0^{\circ} \mathrm{C}$ in the neighbouring area, which is manifested in the coastal zone, around Mamry and Śniardwy Lakes-below 6\%. Throughout most of the country, the analysed share of frosts with the minimum temperature below $-4.0{ }^{\circ} \mathrm{C}$ is from 6 to more than $8 \%$ (Figure 14b).

\section{Conclusions}

Due to ongoing climate warming, the characteristics of frosts should consider not only the calendar basis but also the lengthening of the thermal growing season. The analysis demonstrated that the number of days with frosts in the multiannual period under analysis (1971-2020) from April to October shows a statistically significant shortening, whereas the number of days with frosts recorded in the growing season remains unchanged.

In the climatic conditions of Poland, there is an inter-annual very high variability in the dates of the disappearance of the last spring ground frosts and the dates of the occurrence of the first autumn ground frosts as well as in the number of days with the phenomenon and the duration of frost-free period. Temporal variability of these characteristics is several times higher than that concerning spatial variability, particularly in the central lowland area of Poland, hence there is a need for an ongoing analysis of this phenomenon in Poland.

Ground frosts in spring disappear throughout most of the country, on average, between 10 May and 25 May, and in autumn their occurrence is recorded between 20 September and 5 October, yet the duration of the frost-free period amounts to, on average, 120 to 150 days.

The observed global warming results in the extension of the thermal $\left(\mathrm{AT}>5{ }^{\circ} \mathrm{C}\right)$ growing season from 5 to 7 days over 10 years, particularly in the west of Poland where an increased number of early-spring and late-autumn ground frosts is recorded.

In the thermal growing season, throughout most of the country, the average number of days with ground frosts ranges from 15 to 22 in spring, and in autumn from 8 to 12 days. However, the high frequency and intensity of ground frosts recorded in individual years, generally, is not found throughout the whole area of Poland.

The occurrence of ground frosts in June in Poland, especially in the second half of June, is found to be an exception rather than a rule as it had previously been.

The ongoing warming climate is conducive to the lengthening of the frost-free period from approximately 2 days in the north-east of Poland to approximately 8 days over 10 years in the Pomerania region, mainly owing to the earlier date of disappearance of frosts in spring.

The greatest advance of the dates of the disappearance of the last spring ground frosts is found in the Lubuskie Lakeland, Wielkopolska Lowland and in the Sandomierska Basin. In turn, in autumn, the longest delay of the dates of the occurrence of ground frosts is recorded in Pomerania.

The share of severe and very severe ground frosts in their total number in Poland amounts to $14-18 \%$ in spring, and $6-8 \%$ in autumn.

Despite the unchanged statistically significant number of days with frosts in the thermal growing season in the analysed multiannual period, earlier dates of the disappearance of the last ground frosts in spring and later occurrence of the first frosts in autumn, as well as the extension of the frost-free period, create increasingly more favourable conditions for cultivation of plants with high thermal requirements in Poland. 
The date of liability of the insurer for possible loss of crops due to frosts should take into account the thermal beginning of the growing season and the average date of frost occurrence in spring which vary depending on the region of Poland.

Given the earlier dates of the disappearance of the last ground frosts in spring and later occurrence of the first frosts in autumn, as well as the extension of the frost-free period, the conditions for cultivating plants with high thermal requirements in Poland are found to be increasingly more favourable.

The demonstrated high spatial and temporal discontinuity of ground frosts occurrence in Poland necessitates further research into the frost-related damage to plants; however, taking into consideration the earlier dates of the beginning of the growing season.

Author Contributions: Conceptualization, C.K., J.N.-L., A.M. and B.M.; Data curation, J.N.-L. and A.M.; Formal analysis, C.K., J.N.-L., A.M. and B.M.; Methodology, C.K., J.N.-L., A.M. and B.M.; Resources, J.N.-L. and A.M.; Software, J.N.-L. and A.M.; Visualization, A.M.; Writing—original draft, C.K., J.N.-L., A.M., B.M., Writing-Review \& Editing, J.N.-L. and A.M. All authors have read and agreed to the published version of the manuscript.

Funding: This research received no external funding.

Institutional Review Board Statement: Not applicable.

Informed Consent Statement: Not applicable.

Data Availability Statement: https:/ / danepubliczne.imgw.pl/data/dane_pomiarowo_obserwacyjne/ accessed on 15 April 2021.

Conflicts of Interest: The authors declare no conflict of interest.

\section{References}

1. Niedźwiedź, T. (Ed.) Słownik Meteorologiczny; Polskie Towarzystwo Geofizyczne, Instytut Meteorologii i Gospodarki Wodnej: Warszawa, Poland, 2003; p. 496.

2. Madany, R. O występowaniu przymrozków w różnych masach powietrza. Przegląd Geofiz. 1971, 16, 1-2.

3. Więcław, M. Daily course of air temperature in Bydgoszcz in days with spring and autumn frosts depending on kind of air mass. Pr. I Studia Geogr. 2011, 47, 425-431.

4. Ustrnul, Z.; Wypych, A.; Winkler, J.A.; Czekierda, D. Late spring freezes in Poland in relation to atmospheric circulation. Quaest. Geogr. 2014, 33, 165-172. [CrossRef]

5. Wypych, A.; Ustrnul, Z.; Sulikowska, A.; Chmielewski, F.M.; Bochenek, B. Spatial and temporal variability of the frost-free season in Central Europe and its circulation background. Int. J. Clim. 2017, 37, 3340-3352. [CrossRef]

6. Bielec-Bakowska, Z.; Piotrowicz, K.; Krępa-Adolf, E. Trends in the frost-free season with parallel circulation and air mass statistics in Poland. Idojaras 2018, 122, 375-392. [CrossRef]

7. Tomczyk, A.M.; Szyga-Pluta, K.; Bednorz, E. Occurrence and synoptic background of strong and very strong frost in spring and autumn in Central Europe. Int. J. Biometeorol. 2020, 64, 59-70. [CrossRef] [PubMed]

8. Tomczyk, A. Przymrozki wiosenne i jesienne oraz okres bezprzymrozkowy na Nizinie Wielkopolskiej w latach 1981-2010. In Wspótczesne problemy i kierunki badawcze w geografii; Instytut Geografii i Gospodarki Przestrzennej UJ Kraków: Kraków, Poland, 2015; Volume 3, pp. 245-256.

9. Dragańska, E.; Rynkiewicz, I.; Panfil, M. Częstotliwość i intensywność występowania przymrozków w Polsce północnowschodniej w latach 1971-2000. Acta Agrophysica 2004, 3, 35-42.

10. Bielec-Bąkowska, Z.; Piotrowicz, K. Wieloletnia zmienność okresu bezprzymrozkowego w Polsce w latach 1951-2006. Prace $i$ Studia Geograficzne 2011, 47, 77-86.

11. Dudek, S.; Żarski, J.; Kuśmierek-Tomaszewska, R. Tendencje zmian występowania przymrozków przygruntowych w rejonie Bydgoszczy. Water Environ. Rural Areas 2012, 2, 93-106.

12. Kalbarczyk, R. Spatial and temporal variability of the occurrence of ground frost in Poland and its effect on growth, development and yield of pickling cucumber (Cucumis sativus L.), 1966-2005. Acta Sci. Pol. Hortorum Cultus=Ogrod. 2010, 9, 3-26.

13. Tomczyk, A.; Szyga-Pluta, K.; Majkowska, A. Frost periods and frost free periods in Poland and neighbouring countries. Open Geosci. 2015, 7, 812-823. [CrossRef]

14. Wieteska, S. Ryzyko występowania przymrozków w polskiej strefie klimatycznej. Folia Oeconomica Acta Univ. Lodz. 2011, $259,143-157$.

15. Koźmiński, C.; Trzeciak, S. Przestrzenny i czasowy rozkład przymrozków wiosenno-jesiennych na obszarze Polski. Przegl. Geogr. 1971, 43, 523-549. 
16. Koźmiński, C.; Michalska, B. (Eds.) Atlas klimatycznego Ryzyka Uprawy Roślin w Polsce; Wydawnictwo AR US: Szczecin, Poland, $2001 ;$ p. 81.

17. Koźmiński, C. Występowanie ciagów dni przymrozkowych w okresie wegetacyjnym na terenie Polski. Przegl. Geogr. 1976, $48,75-93$.

18. Marino, G.P.; Kaiser, D.P.; Gu, L.; Ricciuto, D.M. Reconstruction of false spring occurrences over the southeastern United States, 1901-2007: An increasing risk of spring freeze damage? Environ. Res. Lett 2011, 6, 024015. [CrossRef]

19. Koźmiński, C.; Górski, T.; Michalska, B. (Eds.) Atlas klimatyczny Elementów i Zjawisk Szkodliwych dla Rolnictwa w Polsce. AR Szczecin IUNG Puławy: Puławy, Poland, 1990; p. 78.

20. Loginov, V.F.; Mikutskii, V.S.; Kuznetsov, G.P. Statistical and probability analysis of frosts in Belarus. Russ. Meteorol. Hydrol. 2007, 32, 651-657. [CrossRef]

21. Koźmiński, C.; Michalska, B. Niekorzystne zjawiska atmosferyczne w Polsce. In Straty w Rolnictwie: Klimatyczne zagrożenia rolnictwa w Polsce; Koźmiński, C., Michalska, B., Leśny, J., Eds.; Uniwersytet Szczeciński: Szczecin, Poland, 2010 ; pp. 9-54.

22. Easterling, D.R. Recent changes in frost days and the frost-free season in the united states. Bull. Am. Meteorol. Soc. 2002, 83, 1327-1332. [CrossRef]

23. Scheifinger, H.; Menzel, A.; Koch, E.; Peter, C. Trends of spring time frost events and phenological dates in Central Europe. Theor. Appl. Climatol. 2003, 74, 41-51. [CrossRef]

24. Liu, B.; Henderson, M.; Xu, M. Spatiotemporal change in China's frost days and frost free season, 1955-2000. J. Geophys. Res. Atmos. 2008, 113, D12104. [CrossRef]

25. Kozyra, J.; Doroszewski, A.; Nieróbca, A. Zmiany klimatyczne i ich przewidywany wpływ na rolnictwo w Polsce. Studia I Rap. IUNG PIB 2009, 14, 223-257.

26. Malinovic-Milicevic, S.; Stanojevic, G.; Radovanovic, M. Recent changes in first and last frost dates and frost-free period in Serbia. Geogr. Ann.: Ser. A Phys. Geogr. 2018, 100, 44-58. [CrossRef]

27. Frost Protection: Fundamentals, Practice, and Economics. Available online: http://www.fao.org/3/y7223e/y7223e00.pdf\#[0, $\backslash\{\% 22$ name $\% 22: \% 22$ Fit $\% 22 \backslash\}$ (accessed on 15 April 2021).

28. Kolasiński, J. Przymrozki wiosenne i jesienne-występowanie i tendencje zmian w okresie 1966-2005 (na przykładzie Falent). Przegl. Geofiz. 2008, 3-4, 303-310.

29. Bartoszek, K.; Skiba, K.; Dobek, M.; Siłuch, M.; Wereski, S. Frost occurrence in April and May in the Eastern Poland area in the period 1988-2007. Acta Agrophysica Rozpr. I Monogr. 2010, 6, 24-33.

30. Grabowski, J. The occurence of ground frost in the Mazurskie Lakeland between the years 1966 and 2005. Acta Agrophysica Rozpr. I Monogr. 2010, 85, 99-110.

31. Koźmiński, C. Przygruntowe Przymrozki w Polsce w Latach. 1963-1972; PWN: Warszawa, Poland, 1974; Volume 3, p. 52.

32. Żmudzka, E. The climatic background of agricultural production in Poland (1951-2000). Misc. Geogr. 2004, 11, 127-137. [CrossRef]

33. Kożuchowski, K. Klimat Polski, Nowe Spojrzenie; Wydawnictwo Naukowe PWN: Warszawa, Poland, $2011 ;$ p. 294.

34. Radomski, C. Agrometeorologia; PWN: Warszawa, Poland, 1987; p. 544.

35. Woś, A. Meteorologia dla geografów; Wydawnictwo Naukowe UAM: Poznań, Poland, 2006; p. 350.

36. Doroszewski, A.; Żyłowska, K. Ocena szkód w roślinach sadowniczych i ogrodniczych powodowanych przez przymrozki w maju w 2011 roku. Acta Agrophysica 2013, 20, 269-281.

37. Wibig, J.; Głowicki, B. Trends of minimum and maximum temperature in Poland. Clim. Res. 2002, 20, 123-133. [CrossRef]

38. Kożuchowski, K.; Żmudzka, E. Ocieplenie w Polsce: Skala i rozkład sezonowy zmian tem-peratury w drugiej połowie XX w. Przegl. Geofiz. 2001, 46, 81-90.

39. Degirmendžić, J.; Kożuchowski, K.; Żmudzka, E. Changes of air temperature and precipitation in Poland in the period 1951-2000 and their relationship to atmospheric circulation. Int. J. Clim. 2004, 24, 291-310. [CrossRef]

40. Kożuchowski, K.; Degirmendžić, J. Contemporary changes of climate in Poland: Trends and variation in thermal and solar conditions related to plant vegetation. Pol. J. Ecol. 2005, 53, 283-297.

41. Michalska, B. Tendencje zmian temperatury powietrza w Polsce. Pr. I Studia Geogr. 2011, 47, 67-75.

42. Czernecki, B.; Miętus, M. The thermal seasons variability in Poland, 1951-2010. Theor. Appl. Climatol. 2017, 127, 481-493. [CrossRef]

43. Carter, T.R. Changes in the thermal growing season in Nordic countries during the past century and prospects for the future. Agric. Food Sci. 1998, 7, 161-179. [CrossRef]

44. Marsz, A.A.; Żmudzka, E. Oscylacja Północnego Atlantyku a długość okresu wegetacyjnego w Polsce. Przegląd Geofiz. 1999, 4, 199-210.

45. Żmudzka, E. Wieloletnie zmiany zasobów termicznych w okresie wegetacyjnym i aktywnego wzrostu roślin w Polsce. Water Environ. Rural Areas 2012, 12, 377-389.

46. Irannezhad, M.; Kløve, B. Do atmospheric teleconnection patterns explain variations and trends in thermal growing season parameters in Finland? Int. J. Climatol. 2015. [CrossRef]

47. Menzel, A.; Fabian, P. Growing season extended in Europe. Nature 1999, 397, 659. [CrossRef]

48. Chmielewski, F.M.; Rötzer, T. Response of tree phenology to climate change across Europe. Agric. For. Meteor. 2001, 108, 101-112. [CrossRef] 
49. Chmielewski, F.M.; Muller, A.; Bruns, E. Climate changes and trends in phenology of fruit trees and field crops in Germany, 1961-2000. Agric. For. Meteor. 2004, 121, 69-78. [CrossRef]

50. Czarnecka, M.; Nidzgorska-Lencewicz, J. Zmienność termicznej zimy w Polsce w latach 1960-2015. Acta Agroph. 2017, 24, 205-220.

51. Vitasse, Y.; Rebetez, M. Unprecedented risk of spring frost damage in Switzerland and Germany in 2017. Clim. Chang. 2018, 149, 233-246. [CrossRef]

52. Nieróbca, A. Zmiana długości okresu wegetacyjnego w Polsce. Water Environ. Rural Areas 2013, 2, 81-94.

53. Tomczyk, A.M.; Szyga-Pluta, K. Okres wegetacyjny w Polsce w latach 1971-2010. Przeglad Geogr. 2016, 88, 75-86. [CrossRef]

54. Sulikowska, A.; Wypych, A.; Ustrnul, Z.; Czekierda, D. Zmienność Zasobów termicznych w Polsce w aspekcie obserwowanych zmian klimatu. Acta Sci. Pol. Form. Circumiectus 2016, 15, 127-139. [CrossRef]

55. Koźmiński, C.; Mąkosza, A.; Michalska, B.; Nidzgorska-Lencewicz, J. Thermal conditions for viticulture in Poland. Sustainability 2020, 12, 5665. [CrossRef]

56. Rodrigo, J. Spring Frost in deciduous fruit trees-morphological damage and flower hardiness. Sci. Hort. 2000, 85, 155-173. [CrossRef]

57. Kunkel, K.E.; Easterling, D.R.; Hubbard, K.; Redmond, K. Temporal variations in frost-free season in the United States: 1895-2000. Geophys. Res. Lett. 2004, 31, L03201. [CrossRef]

58. Lhotka, O.; Brönnimann, S. Possible Increase of Vegetation Exposure to Spring Frost under Climate Changein Switzerland. Atmosphere 2020, 11, 391. [CrossRef]

59. Gumiński, R. Próba wydzielenia dzielnic rolniczo-klimatycznych w Polsce. Przegl. Met. I Hydr. 1948, 1, 7-20.

60. Ustawa z Dnia 7 Lipca 2005 r. o Ubezpieczeniach Upraw Rolnych i Zwierzat Gospodarskich (sejm.gov.pl). Available online: http:/ / eli.sejm.gov.pl/eli/DU/2005/1249/ogl/pol (accessed on 15 April 2021).

61. Top Agrar Polska. Available online: https://www.topagrar.pl/articles/top-uprawa/przymrozek-wiosenny-prawo-nie-nadazaza-zmiana-klimatu/ (accessed on 15 April 2021).

62. Krajowa Rada Izb Rolniczych. Available online: http://www.krir.pl/2014-01-03-03-24-03/produkcja-roslinna/6811-przymrozkiwiosenne-potrzeba-zmian-systemu-ubezpieczen (accessed on 15 April 2021).

63. Portal Sadowniczy: E-sadownictwo.pl. Available online: https://www.e-sadownictwo.pl/wiadomosci/z-kraju/7351 -przymrozki-a-ubezpieczenie-ministerstwo-odpowiada (accessed on 15 April 2021). 